\title{
Synthetic Aluminosilicates for Geopolymer Production
}

\author{
Mariana Arruda Pereira ${ }^{\circledR}{ }^{\circledR}$, Daniela C. Leite Vasconcelos ${ }^{b}$, Wander Luiz Vasconcelos $^{b}$
}

\author{
${ }^{a}$ Departamento de Tecnologia em Engenharia Civil, Computação e Humanidades, Universidade Federal \\ São João del-Rei - UFSJ, Campus Alto Paraopeba, Rodovia MG $443 \mathrm{Km} 7$ - Fazenda do Cadete, Caixa \\ Postal 131, CEP 36420-000, Ouro Branco, MG, Brasil \\ ${ }^{b}$ Departamento de Engenharia Metalúrgica e de Materiais, Universidade Federal de Minas Gerais - \\ UFMG, Avenida Presidente Antônio Carlos, 6627, Campus UFMG, Escola de Engenharia, bloco 2, \\ CEP: 31270-901, Belo Horizonte, MG, Brasil
}

Received: July 19, 2018; Revised: November 06, 2018; Accepted: December 19, 2018

\begin{abstract}
The use of geopolymer has been studied as a potential substitute for Portland cement due to lower $\mathrm{CO}_{2}$ emission and improvements on structural properties. Some of the major raw materials used in the manufacture of the geopolymer are: steel slag, fly ash and metakaolinite. Due to the impurities contained in these raw materials, the present study uses high purity synthetic aluminosilicates made from the sol gel process for production of geopolymers. The samples were characterized by X-ray diffraction (XRD), Fourier transform infrared spectroscopy (FTIR), scanning electron microscopy (SEM) and nuclear magnetic resonance (NMR). The results showed that the synthetic aluminosilicates have similar behavior to metakaolinite (reference). It was found that the coordination of $\mathrm{Al}$ in the synthetic aluminosilicate changed from VI to IV and V from $300{ }^{\circ} \mathrm{C}$, with the highest intensity at $900{ }^{\circ} \mathrm{C}$. Temperature at which the highest mechanical strength of the geopolymer was also observed.
\end{abstract}

Keywords: Synthetic aluminosilicates, geopolymer, sol-gel process, metakaolinite.

\section{Introduction}

Portland cement concrete is a versatile material with relatively low costs, becoming one of the world's most consumed materials. Nevertheless, major drawbacks are attributed to the production of this material, such as high $\mathrm{CO}_{2}$ emission rates to the atmosphere ${ }^{1}$. The concrete lifespan is another inconvenience due to limitations concerning its porous nature. These restrictions foster the need of alternative materials to Portland cement such as geopolymers. In a pioneer study by Joseph Davidovits in $1970^{2}$, this term was introduced to describe a class of solid materials synthesized by the reaction of powdered aluminum silicate with an alkaline solution, forming an inorganic polymer ${ }^{3,4}$.The application of geopolymers is not limited to the use in civil construction, having potential to be used as: fireproof material, refractory, composites for repair of toxic and radioactive waste reservoir, decorative artifacts ${ }^{2}$, electrical conductors ${ }^{5}$, biomaterials ${ }^{6}$, storage and gas capture ${ }^{7}$ and others.

The geopolymer is a hydrated aluminosilicate mineral with a polymeric structure. It consists of materials with activated $\mathrm{Si}$ and $\mathrm{Al}$ in solutions with medium to high alkalinity. The reaction between $\mathrm{Si}$ and $\mathrm{Al}$ forms a precursor that bind to other activated molecules provided that the alkaline medium is maintained. The result is a network formed by covalent bonds in a three-dimensional structure ${ }^{2}$. The chaotic spatial configuration obtained between the sialates make the structure predominantly amorphous ${ }^{2}$.
Several materials can be used as raw material for geopolymer production, such as: fly ash ${ }^{8-12}$; metakaolin ${ }^{13-17}$; blast furnace slag ${ }^{18,19}$ and even Portland cement ${ }^{9}$. But these materials have substances other than the aluminosilicate required for the geopolymerization reactions, interfering with the reactions, such as other oxides besides those associated with $\mathrm{Al}$ and $\mathrm{Si}$. In order to produce a high purity material in this study, a synthetic aluminosilicate (S-AS) was produced by the sol-gel process. The use of the sol-gel process for the production of aluminosilicates, in addition to allowing partial control of the granulometry and variation of the composition, allows changes in the molar ratios, especially $\mathrm{Si}$ and $\mathrm{Al}$, which will have a direct influence on the final properties of the geopolymer. This work aimed at the production of a synthetic aluminosilicate with $\mathrm{Si} / \mathrm{Al}$ molar ratios similar to that of some kaolinites, but without common oxides found in natural materials (such as $\mathrm{Fe}_{2} \mathrm{O}_{3}, \mathrm{CaO}, \mathrm{MgO}, \mathrm{K}_{2} \mathrm{O}, \mathrm{TiO}_{2}$ ).

The powder was then submitted to a chemical activation for the geopolymerization process using a sodium hydroxide solution. The characteristics of the synthetic powders and the geopolymers produced from these powders were studied by means of XRD, SEM and NMR ${ }^{2,15,20-26}$. NMR spectra are generally considered the most important test for characterization of raw materials for the production of geopolymer, specifically the ${ }^{27} \mathrm{Al}$ spectrum. From this technique it is possible to evaluate the coordination of $\mathrm{Al}$, an essential factor in the evaluation of the potential of activation of the raw material. 


\section{Experimental}

\subsection{Materials}

The synthetic aluminosilicate powder was obtained by the sol-gel process using aluminum tri-sec-butoxide and tetraethyl orthosilicate (TEOS) as Al and Si precursors, respectively. Ethanol and ammonia were mixed with the following molar proportions were: $\mathrm{Si} / \mathrm{Al}=1, \mathrm{EtOH} / \mathrm{SiO}_{2}=24$ and $\mathrm{SiO}_{2} / \mathrm{H}_{2} \mathrm{O}=16$ and $\mathrm{H}_{2} \mathrm{O} / \mathrm{NH}_{4} \mathrm{OH}=8$. Reagents were mixed and maintained at room temperature under stirring for $12 \mathrm{~h}$ and at rest for additional $12 \mathrm{~h}$. The solution was further vacuum filtered and dryed at $100{ }^{\circ} \mathrm{C}$ for $24 \mathrm{~h}$. Then the powder was heat at temperatures varying within 200 $1000{ }^{\circ} \mathrm{C}$ for $2 \mathrm{~h}$. The metakaolim (Metacaulim do Brasil) was used as reference material and its composition was analyzed using of X-ray fluorescence for the quantification of the material necessary for the production of the samples. The results were, in mass $\%: \mathrm{SiO}_{2}=53.40 ; \mathrm{Al}_{2} \mathrm{O}_{3}=40.61$; $\mathrm{Fe}_{2} \mathrm{O}_{3}=2.77 ; \mathrm{TiO}_{2}=1.55 ; \mathrm{K}_{2} \mathrm{O}=1.27 ; \mathrm{MgO}=0.22 ; \mathrm{CaO}=$ $0.11 ; \mathrm{SO}_{3}=0.06 ; \mathrm{PbO}=0.01$ and $\mathrm{CuO}=0.01$.

\subsection{Geopolymer synthesis}

For geopolymer production, initially the solutions containing water, silicate and sodium hydroxide were prepared. These solutions remained at rest and at room temperature for 24 hours. Subsequently, the solution was mixed with the synthetic aluminosilicate calcined in a vessel kept in an ice bath to minimize the effects of temperature because the temperature accelerates the reactions of geopolymerization, making it difficult to mold the pastes. The molar ratio of the components were: $\mathrm{Na}_{2} \mathrm{O} / \mathrm{SiO}_{2}=0.68 ; \mathrm{SiO}_{2} / \mathrm{Al}_{2} \mathrm{O}_{3}=3.2$ e $\mathrm{H}_{2} \mathrm{O} / \mathrm{Na}_{2} \mathrm{O}=6.7$

For mechanical tests, the geopolymer slurry was poured into cylindrical molds after mixing for one minute. The dimension of the specimens used to evaluate the compressive strength was $5 \times 10 \mathrm{~mm}$ in order to maintain the ratio of $1: 2$, as recommended in the standards NBR $7215-1996^{27}$ and ASTM C39 - $2016^{28}$. After the molding process, the mold was sealed and placed in an oven for 24 hours at a temperature of $60{ }^{\circ} \mathrm{C}$. Subsequently, the specimens were removed from the molds and kept at room temperature $\left(23^{\circ} \mathrm{C}\right.$ $\pm 2{ }^{\circ} \mathrm{C}$ ) until the final curing age. For the other analyzes, the same conditions of cure were maintained, however, without concern for the shape of the specimens.

\subsection{Characterization}

The solid structure of the powders calcined at different temperatures and of the geopolymer was analyzed by X-ray diffraction (XRD) (Empyream Panalytical, radiation with copper tube and xenon detector). The infrared spectroscopy (Perkin Elmer - Paragon 1000) was performed with analysis range from $4000 \mathrm{~cm}^{-1}$ to $400 \mathrm{~cm}^{-1}, 128$ scans and resolution of $2 \mathrm{~cm}^{-1}$.
The morphology analysis of the powders and of the geopolymer was performed using a scanning electron microscope (Quanta FEG 3D FEI). The compressive strength of the geopolymer was assessed by an universal test machine (Instron, model 5882) with loading speed of $0.5 \mathrm{~mm} / \mathrm{min}$, as adopted by other authors ${ }^{23}$.

The MAS NMR spectra of ${ }^{27} \mathrm{Al}$ and ${ }^{29} \mathrm{Si}$ isotopes of the synthetic aluminosilicates and the geopolymer were obtained using an Avance III 400WB HD spectrometer. Frequencies of $14 \mathrm{kHz}$ for $\mathrm{Al}$ and $10 \mathrm{kHz}$ for Si were used.

\section{Results and Discussion}

\subsection{XRD analysis}

XRD diffractograms (Figure 1) show that the peaks attributed to the synthetic aluminosilicate (S-AS) samples range from $22^{\circ}$ to $25^{\circ}$, while the peak of the geopolymer sample cured at $60{ }^{\circ} \mathrm{C}$ occurs at approximately $28^{\circ}$. The samples show peaks in the region within $15^{\circ}$ and $35^{\circ}$, similar to observed in the XRD spectrum of metakaolinite ${ }^{2}$. The lack of intense peaks indicates amorphous structure in all samples. Peaks with $2 \theta$ values of $46^{\circ}$ and $67^{\circ}$ on the XRD spectrum of the samples heat treated at $1000{ }^{\circ} \mathrm{C}$ confirm initial crystallization. It is also noted that, unlike that of kaolinite (structure of metakaolin before heat treatment), which is crystalline at $100{ }^{\circ} \mathrm{C}$, the aluminosilicate of the present work is amorphous at that temperature.

The structure of synthetic materials is typically amorphous, with absence of an atomic structure and its structure is similar metakaolinite ${ }^{2}$. However, according to the Scherrer equation, the change in the angle $2 \theta$ may be due to the increase of the ordered molecular structure with the temperature increase ${ }^{5}$. Thus, after heat treatments, the short-range of $\mathrm{Al}_{2} \mathrm{O}_{3}-2 \mathrm{SiO}_{2}$ is exported to be more ordered than in the samples before heat treatment.

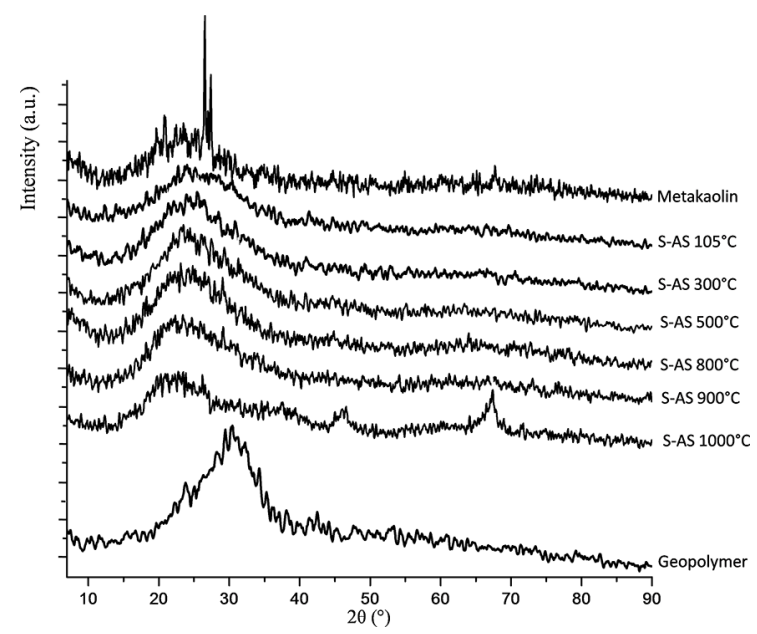

Figure 1. XRD pattern of the geopolymer, the synthetic powders at different heat treatment temperatures and metakaolin. 


\subsection{Morphological analysis}

Figure 2 illustrates SEM micrographs of the synthetic aluminosilicate heat treated at $900{ }^{\circ} \mathrm{C}$. The Figure 2a shows an irregular layer structure, different from what was observed in metakaolin ${ }^{5}$, which has many particle agglomerates. It is also observed in the Figure $2 b$ the presence of the spherical particles indicating the presence of pure unreacted silica.

\subsection{FTIR analysis}

Figure 3 represents the FTIR spectra of synthetic aluminosilicate and natural aluminosilicate (metakaolin), while Figure 4 shows the spectra of synthetic aluminosilicate and geopolymers made with the power heat treated at $900{ }^{\circ} \mathrm{C}$.

In Figures 3 and 4 bands at $3450 \mathrm{~cm}^{-1}$ show a broad band which is attributed to the overlap of the O-H group, with stretching of water molecules bond by hydrogen $(\mathrm{H}-\mathrm{O}-\mathrm{H})$ and silanols groups, $\mathrm{SiO}-\mathrm{H}$, bound to the molecular water, observed in the non-heat treated samples.

The band at $1640 \mathrm{~cm}^{-1}$ is also characteristic of hydroxyl group. At $1380 \mathrm{~cm}^{-1}$, the band can be attributed to the / group due to the presence of ammonia (used in sol-gel process), which is removed after the heat treatment at temperatures above $400{ }^{\circ} \mathrm{C}$. At $1100 \mathrm{~cm}^{-1}$ and $1040 \mathrm{~cm}^{-1}$, the intense bands correspond to the asymmetric stretches and vibrations of Si-O-Si and Si-Al-O, respectively.

Covalent bonds reveal the existence of a dense silica network ${ }^{2}$, in which oxygen atoms act as bridges between two silicon atoms ( $\mathrm{Si}-\mathrm{O}-\mathrm{Si}$ ) in asymmetric stretching vibration. The bands with wave number of $874 \mathrm{~cm}^{-1}$ in the S-AS $105^{\circ} \mathrm{C}$ spectrum can be attributed to the overlapping of the bands typical of the $\mathrm{Al}(\mathrm{VI})-\mathrm{O}$ and $\mathrm{Si}-\mathrm{OH}$ vibration bonds. Bands at $914 \mathrm{~cm}^{-1}$ indicates $\mathrm{Al}(\mathrm{VI})-\mathrm{O}$ bonds ${ }^{29}$ and the band at $840 \mathrm{~cm}^{-1}$ occurs due to Si-OH bonds ${ }^{2}$. The bands at $880 \mathrm{~cm}^{-1}$ e $808 \mathrm{~cm}^{-1}$ refer to the frequency of $\mathrm{Al}(\mathrm{V})-\mathrm{O}$ and $\mathrm{Al}(\mathrm{IV})-\mathrm{O}$, respectively, on the S-AS $800^{\circ} \mathrm{C}$ and $900^{\circ} \mathrm{C}$

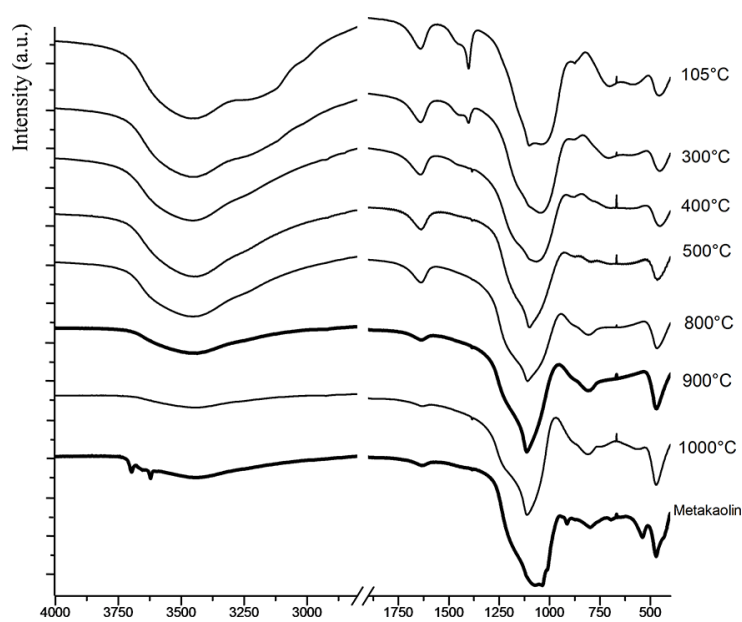

Figure 3. FTIR spectra of powders heat treated at different temperatures and natural metakaolin.

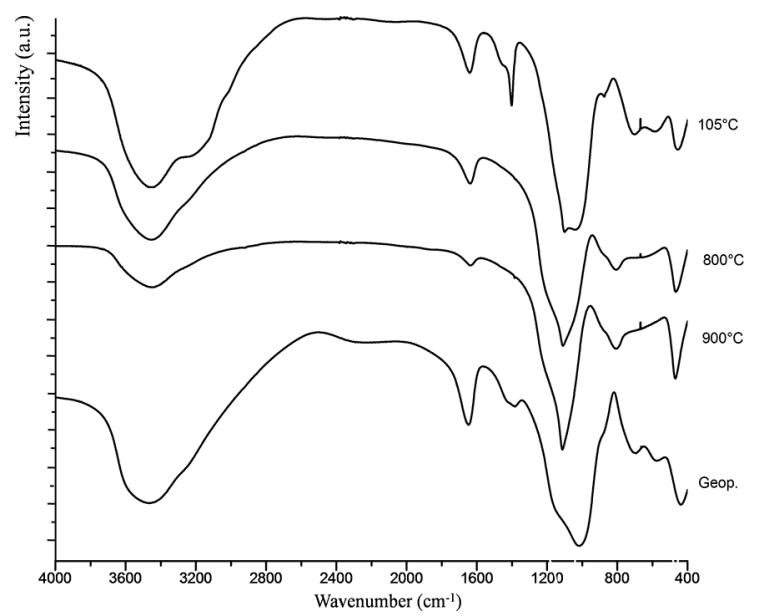

Figure 4. FTIR spectra of powders heat treated at $105^{\circ} \mathrm{C}, 800{ }^{\circ} \mathrm{C}$, $900{ }^{\circ} \mathrm{C}$ and geopolymer.
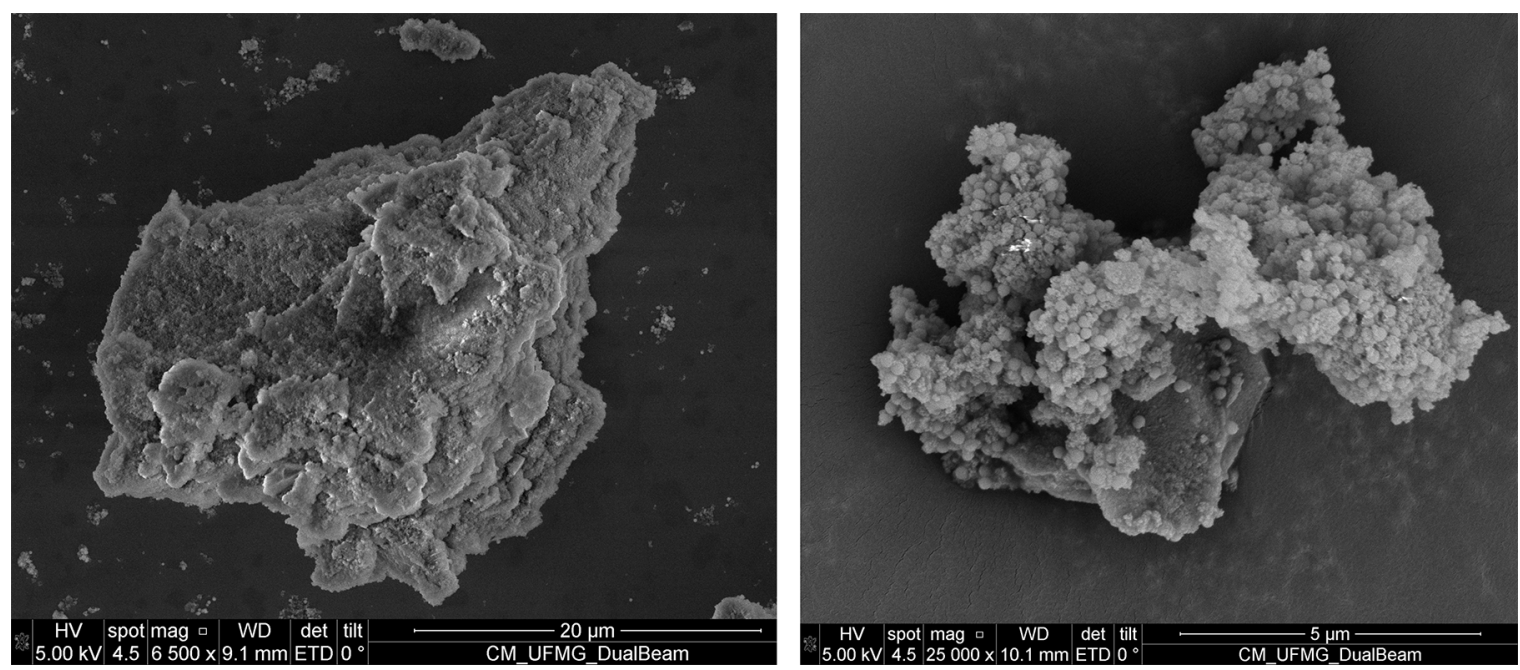

Figure 2. SEM images of synthetic aluminosilicate heat treated of $900{ }^{\circ} \mathrm{C}$ by secondary electrons: (a) structure and (b) structure with agglomerated silica. 
spectra. This result indicates the alteration of Al coordination from VI at $105{ }^{\circ} \mathrm{C}$ for IV e V coordination at $800{ }^{\circ} \mathrm{C}$ e $900{ }^{\circ} \mathrm{C}$ temperatures. The spectra in the frequencies between $800 \mathrm{~cm}^{-1}$ and $480 \mathrm{~cm}^{-1}$ correspond to the symmetry of the $\mathrm{Si}-\mathrm{O}-\mathrm{Si}$ stretching vibration. The peaks at approximately $1100 \mathrm{~cm}^{-1}, 910 \mathrm{~cm}^{-1}, 800 \mathrm{~cm}^{-1}$ e $460 \mathrm{~cm}^{-1}$ of the S-AS $900{ }^{\circ} \mathrm{C}$ curve are similar to those in metakaolin, Figure 3, indicating the similarity between the materials and its potential for the production of geopolymer.

Figure 4 details the spectra of aluminosilicates and the geopolymer produced from the powder heat treated at $900{ }^{\circ} \mathrm{C}$. The geopolymer FTIR spectrum shows that bands related to hydroxyl group at $3475 \mathrm{~cm}^{-1}$ and $1648 \mathrm{~cm}^{-1}$. The bands at $1420 \mathrm{~cm}^{-1}$ and $1380 \mathrm{~cm}^{-1}$ in the geopolymer spectrum indicate the presence of sodium carbonate $\left(\mathrm{Na}_{2} \mathrm{CO}_{3}\right)$ due to the presence of free $\mathrm{NaOH}$ and water in the geopolymer preparation. The Na migrates to the surface and reacts with atmospheric $\mathrm{CO}_{2}$. The kneading water initially participates in the synthesis of the geopolymer by dissolving the solid aluminosilicate by alkaline hydrolysis (consuming the water) then the aluminates and silicates condense to produce the geopolymer network and water as a by-product. In this way the bands referring to the $\mathrm{OH}$ group reappear intense in the geopolymer.

It is also possible to notice in the geopolymer spectrum the intense band at $1018 \mathrm{~cm}^{-1}$ which corresponds to the Si-OAl bond, replacing the Si-O-Si bond of S-AS $900{ }^{\circ} \mathrm{C}$ (band $1080 \mathrm{~cm}^{-1}$ ). The region between $800 \mathrm{~cm}^{-1}$ and $500 \mathrm{~cm}^{-1}$, reveal several weak bands attributed to the flexion of the Al-O-Si bond, that replaced the $808 \mathrm{~cm}^{-1}$ band in the S-AS $900^{\circ} \mathrm{C}$ curve (due to the polyhedrons $A l O_{x}$ ). The $439 \mathrm{~cm}^{-1}$ peak in the geopolymer relative to $\mathrm{Si}-\mathrm{O}$ bond while in powders this bond manifest at approximately $456 \mathrm{~cm}^{-1}$.

\subsection{NMR spectra}

The results of the ${ }^{27} \mathrm{Al}$ isotopes analysis of the heat treated powders at $105{ }^{\circ} \mathrm{C}, 300{ }^{\circ} \mathrm{C}, 900{ }^{\circ} \mathrm{C}$ e $1000{ }^{\circ} \mathrm{C}$ are
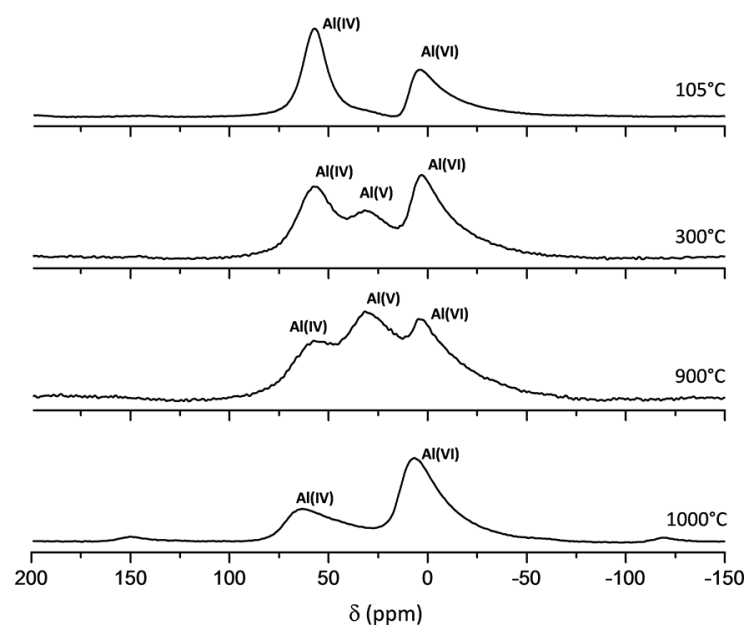

Figure 5. ${ }^{27} \mathrm{Al}$ NMR spectra of the synthetic aluminosilicate heat treated at $100{ }^{\circ} \mathrm{C}, 300{ }^{\circ} \mathrm{C}, 900{ }^{\circ} \mathrm{C}$ and $1000^{\circ} \mathrm{C}$. displayed in Figure 5. The resonance at approximately 0 ppm, 25 - 30 ppm and 55 - 60 ppm indicate, respectively, the presence of aluminum at coordination VI, V and IV. It can be observed that the samples heat treated at $105^{\circ} \mathrm{C}$ do not indicate the presence of $\mathrm{Al}(\mathrm{V})$ which is responsible for making the aluminosilicate capable of being activated in the geopolymerization reactions ${ }^{2}$.

By means of this technique it is possible to quantify the relative coordination of $\mathrm{Al}$, as noticed in Figure 6 . The peak areas of the ${ }^{27} \mathrm{Al}$ spectrum after deconvolution represent the ratio of each binding ${ }^{30}$. Then, in Figure 6, the deconvolution of the three peaks present in the heat treated powders at $900{ }^{\circ} \mathrm{C}$. From the deconvolution it is possible to calculate the area of each peak and infer the proportion of each link, note the presence of $36 \%$ of $\mathrm{Al}(\mathrm{V}), 34 \%$ of $\mathrm{Al}(\mathrm{VI})$ and $30 \%$ of $\mathrm{Al}$ (IV).

From the spectra of ${ }^{29} \mathrm{Si}$, Figure 7 , broad peaks are observed in calcined aluminosilicates heat treated at $105^{\circ} \mathrm{C}$ to $900{ }^{\circ} \mathrm{C}$. It is suggested that there is overlapping of the peaks and that $\mathrm{Al}$ present on the aluminosilicate network causes the displacement of the ${ }^{29} \mathrm{Si}$ spectra. Results previously reported

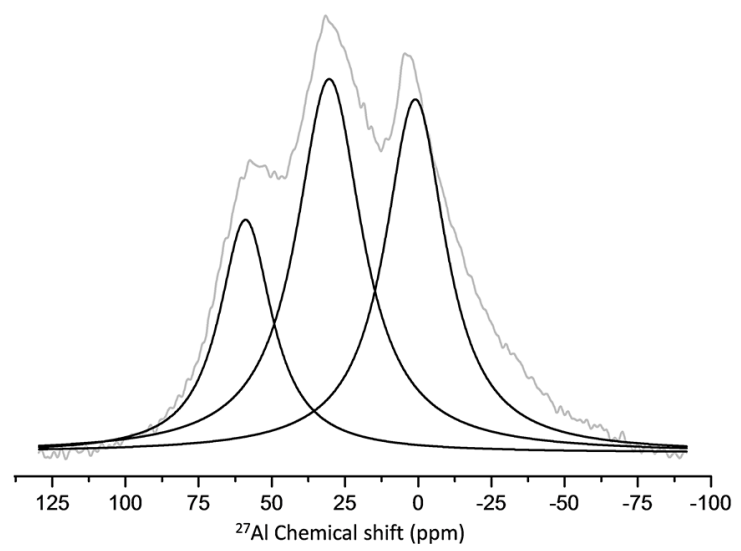

Figure 6. ${ }^{27} \mathrm{Al}$ NMR spectrum deconvolution of the synthetic aluminosilicate heat treated at $900^{\circ} \mathrm{C}$, with coefficient of determination $\left(r^{2}\right)=0.992$.

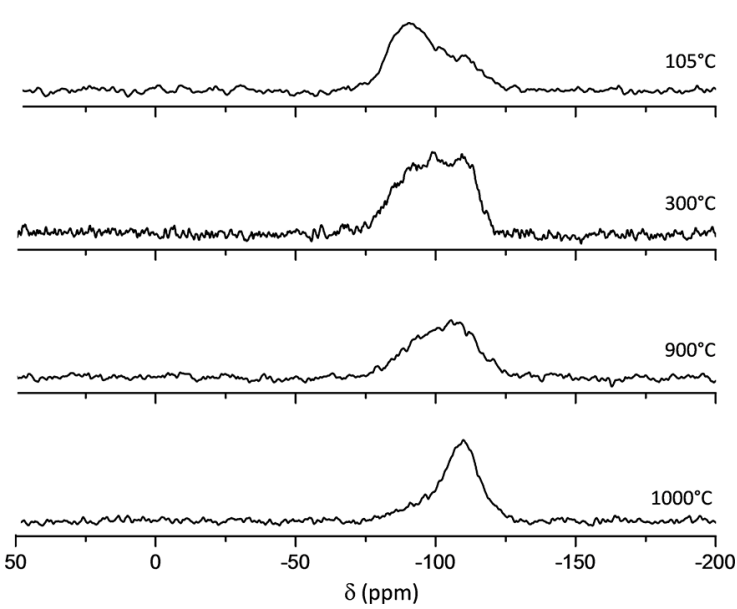

Figure 7. ${ }^{29} \mathrm{Si}$ NMR spectra of the synthetic aluminosilicate heat treated at $105^{\circ} \mathrm{C}, 300{ }^{\circ} \mathrm{C}, 900{ }^{\circ} \mathrm{C}$ and $1000{ }^{\circ} \mathrm{C}$. 
in the literature ${ }^{2,31}$ indicate that each $\mathrm{AlO}_{4}$ unit connected to the $\mathrm{SiO}_{4}$ group shift the ${ }^{29} \mathrm{Si}$ by $5 \mathrm{ppm}$ in the ${ }^{29} \mathrm{Si}$ spectra. In addition, the average peak value shifts to a smaller value and the peak becomes more acute, indicating the decrease of Al in the Si sphere. Thus, at $1000^{\circ} \mathrm{C}$, increasing intensity with peak thinning and shifting of the chemical shift to a smaller value indicates the formation of crystalline silica, confirmed by XDR analyzes. As observed by other authors ${ }^{30}$, the presence of Al in the Si bonds, changes to a value higher than the ${ }^{29} \mathrm{Si}$ chemical shift.

\subsection{Compressive strengths}

Compressive tests, Table 1, showed that the powers dried at $100^{\circ} \mathrm{C}$ and $200{ }^{\circ} \mathrm{C}$ do not have polycondensation activity, with very low mechanic resistance, whereas the powders calcined above $300{ }^{\circ} \mathrm{C}$ exhibit enough alkaline polycondensation activity. Since the synthetic aluminosilicate of this work is amorphous, as shown in XDR results, this does not make it sufficient amenable to being activated. At $1000{ }^{\circ} \mathrm{C}$ the samples also did not present mechanical resistance, indicating that there was no polycondensation. A tendency also is observed to increase the mechanical strength as the heat treatment temperature of the synthetic

Table 1. Compressive strength of Na-geopolymers produced from powders heat treated at different temperatures.

\begin{tabular}{lllllllll}
\hline $\begin{array}{l}\text { Powder } \\
\text { treatment } \\
\text { temperature } \\
\left({ }^{\circ} \mathrm{C}\right)\end{array}$ & 200 & 300 & 400 & 500 & 600 & 700 & 800 & 900 \\
\hline $\begin{array}{l}\text { Maximum } \\
\text { compressive } \\
\text { strength } \\
(\mathrm{MPa})\end{array}$ & 0 & 4.3 & 4.8 & 4.4 & 5.4 & 5.9 & 6.1 & 9.9 \\
\hline
\end{tabular}

powders, indicating the gradual increase of the presence of $\mathrm{Al}(\mathrm{IV})$ and (V) with increasing temperature.

The characteristics noted by the NMR technique corroborate the results of the compressive strength tests that only show the mechanical strength for materials heat treated above $300{ }^{\circ} \mathrm{C}$. The highest compressive strength was obtained for sample heat treated at $900{ }^{\circ} \mathrm{C}$ and above this temperature there is no mechanical resistance again, indicating the importance of the presence of $\mathrm{Al}(\mathrm{V})$ in the geopolymerization reactions.

An increase in mechanical strength is expected with the improvement of the interaction of $\mathrm{Al}$ and $\mathrm{Si}$ in the sol gel synthesis process, since the presence of unreacted silica was observed in SEM images. Thus, changes in the productive process in order to make the interaction more effective are still being investigated by the authors.

\section{Conclusions}

The pure synthetic aluminosilicate developed in this study by the sol-gel route was confirmed as a potential alternative for the production of geopolymer, exhibiting characteristics similar to the reference natural aluminosilicate (metakaolin). Geopolymerization of aluminosilicate is possible when the $\mathrm{Al}$ with coordination numbers of IV and $\mathrm{V}$ are present, which is obtained by heat treatment. By the results of the NMR and FTIR analyses, the presence of Al (IV) and (V) in the synthetic aluminosilicate were confirmed, while is compatible with the results of the tests of resistance to compression.

Highest values of mechanical resistance were obtained for the geopolymer produced from the powder heat treated at $900{ }^{\circ} \mathrm{C}$. For heat treatments below $300{ }^{\circ} \mathrm{C}$ and above $900{ }^{\circ} \mathrm{C}$ there was no observed polymerization. Since it is a pure synthetic material, it can be used in more noble applications that require higher purity.

\section{Acknowledgments}

The authors would like to thank our partners: Electron Microscopy Center of UFMG, LAQ-DEMET/UFMG, INCT - Acqua and the Nuclear Technology Development Center - CDTN. The company Metacaulim of Brazil and Graintec industry and commerce by providing samples. And to the MNR laboratory of the Chemistry Institute of UNESP for the resonance analysis.

\section{References}

1. Cimento.org. O mundo do cimento. Available from: $<w w w$. cimento.org >. Access in: 15/10/2018.

2. Davidovits J. Geopolymer - Chemistry and Applications. SaintQuentin: Institut Géopolymère; 2011.612 p.

3. Davidovits J, ed. Geopolymers, Green Chemistry and Sustainable Development Solutions. Proceedings of the Geopolymer 2005 World Congress. Saint-Quentin: Institut Géopolymère; 2005.

4. Provis JL, van Deventer JSJ. Geopolymer: Structure, processing, properties and industrial applications. Oxford: Woodhead Publishing; 2009.

5. Cui XM, Zheng GJ, Han YC, Su F, Zhou J. A study on electrical conductivity of chemosynthetic A12O3-2SiO2 geopolymer materials. Journal of Power Sources. 2008;184(2):652-656.

6. Catauro M, Bollino F, Papale F, Lamanna G. Investigation of the sample preparation and curing treatment effects on mechanical properties and bioactivity of silica rich metakaolin geopolymer. Materials Science and Engineering: C. 2014;36:20-24.

7. Minelli M, Medri V, Papa E, Miccio F, Landi E, Doghieri F. Geopolymers as solid adsorbent for $\mathrm{CO} 2$ capture. Chemical Engineering Science. 2016;148:267-274. 
8. Abdulkareem OA, Al Bakri AMM, Kamarudin H, Khairul Nizar I, Saif AA. Effects of elevated temperatures on the thermal behavior and mechanical performance of fly ash geopolymer paste, mortar and lightweight concrete. Construction and Building Materials. 2014;50:377-387.

9. Pangdaeng S, Phoo-ngernkham T, Sata V, Chindaprasirt P. Influence of curing conditions on properties of high calcium fly ash geopolymer containing Portland cement as additive. Materials \& Design. 2014;53:269-274.

10. Nath SK, Kumar S. Influence of iron making slags on strength and microstructure of fly ash geopolymer. Construction and Building Materials. 2013;38:924-930. DOI: http://dx.doi. org/10.1016/j.conbuildmat.2012.09.070

11. Vora PR, Dave UV. Parametric Studies on Compressive Strength of Geopolymer Concrete. Procedia Engineering. 2013;51:210-219. DOI: http://dx.doi.org/10.1016/j. proeng.2013.01.030

12. Phoo-ngernkham $T$, Chindaprasirt $P$, Sata V, Hanjitsuwan $S$, Hatanaka S. The effect of adding nano-SiO2 and nano-A12O3 on properties of high calcium fly ash geopolymer cured at ambient temperature. Materials \& Design. 2014;55:58-65. DOI: http://dx.doi.org/10.1016/j.matdes.2013.09.049

13. Vassalo EAS. Obtenção de geopolímero a partir de metacaulim ativado. [Dissertation]. Belo Horizonte: Universidade Federal de Minas Gerais; 2013.

14. Zhang Y, Sun W, Li Z. Composition design and microstructural characterization of calcined kaolin-based geopolymer cement. Applied Clay Science. 2010;47(3-4):271-275.

15. Duxson P, Provis JL, Lukey GC, Mallicoat SW, Kriven WM, van Deventer JSJ. Understanding the relationship between geopolymer composition, microstructure and mechanical properties. Colloids and Surfaces A: Physicochemical and Engineering Aspects. 2005;269(1-3):47-58.

16. Rahier H, Simons W, Van Mele B, Biesemans M. Lowtemperature synthesized aluminosilicate glasses: Part III Influence of the composition of the silicate solution on production, structure and properties. Journal of Materials Science. 1997;32(9):2237-2247.

17. Phair JW, Smith JD, Van Deventer JSJ. Characteristics of aluminosilicate hydrogels related to commercial "Geopolymers". Materials Letters. 2003;57(28):4356-4367.

18. Giasuddin HM, Sanjayan JG, Ranjith PG. Strength of geopolymer cured in saline water in ambient conditions. Fuel. 2013;107:34-39. DOI: http://dx.doi.org/10.1016/j. fuel.2013.01.035
19. Islam A, Alengaram UJ, Jumaat MZ, Bashar II. The development of compressive strength of ground granulated blast furnace slagpalm oil fuel ash-fly ash based geopolymer mortar. Materials \& Design (1980-2015). 2014;56:833-841.

20. Cui X, Liu L, Zheng G, Wang R, Lu J. Characterization of chemosynthetic Al2O3-2SiO2 geopolymers. Journal of NonCrystalline Solids. 2010;356(2):72-76.

21. Duxson P, Fernández-Jiménez A, Provis JL, Lukey GC, Palomo A, van Deventer JSJ. Geopolymer technology: The current state of the art. Journal of Materials Science. 2007;42(9):2917-2933.

22. Hairi SNM, Jameson GNL, Rogers JJ, MacKenzie KJD. Synthesis and properties of inorganic polymers (geopolymers) derived from Bayer process residue (red mud) and bauxite. Journal of Materials Science. 2015;50(23):7713-7724.

23. He Y, Liu L, He L, Cui X. Characterization of chemosynthetic H3PO4-A12O3-2SiO2 geopolymers. Ceramics International. 2016;42(9):10908-10912.

24. Lyu SJ, Hsiao YH, Wang TT, Cheng TW, Ueng TH. Microstructure of geopolymer accounting for associated mechanical characteristics under various stress states. Cement and Concrete Research. 2013;54:199-207.

25. Provis JL, van Deventer JSJ. Geopolymerisation kinetics. 2. Reaction kinetic modelling. Chemical Engineering Science. 2007;62(9):2318-2329.

26. Wan Q, Rao F, Song S, García RE, Estrella RM, Patiño CL, et al. Geopolymerization reaction, microstructure and simulation of metakaolin-based geopolymers at extended $\mathrm{Si} / \mathrm{Al}$ ratios. Cement and Concrete Composites. 2017;79:45-52. DOI: http:// linkinghub.elsevier.com/retrieve/pii/S0958946517301002

27. Associação Brasileira de Normas Técnicas (ABNT). NBR 7215 - Cimento Portland: Determinação da resistência à compressão. Rio de Janeiro: ABNT; 1996.

28. ASTM International. ASTM C39 / C39M-99 - Standard Test Method for Compressive Strength of Cylindrical Concrete Specimens. West Conshohocken: ASTM International; 1999.

29. Catauro M, Bollino F, Cattaneo AS, Mustarelli P. $\mathrm{Al}_{2} \mathrm{O}_{3} \cdot 2 \mathrm{SiO}_{2}$ powders synthesized via sol-gel as pure raw material in geopolymer preparation. Journal of the American Ceramic Society. 2017;100(5):1919-1927.

30. Bell AT, Pines A. NMR Techniques in Catalysis. New York: Marcel Dekker; 1994

31. Müller D, Gessner W, Behrens HJ, Scheler G. Determination of the aluminum coordination in aluminum-oxygen compounds by solid-state high resolution 27Al NMR. Chemical Physics Letters. 1981;79(1):59-62. 